\title{
Building 251 Radioactive Waste Characterization by Process Knowledge
}

\author{
J.L. Dominick
}

May 29, 2002

Lawrence

Livermore

National

Laboratory 


\section{DISCLAIMER}

This document was prepared as an account of work sponsored by an agency of the United States Government. Neither the United States Government nor the University of California nor any of their employees, makes any warranty, express or implied, or assumes any legal liability or responsibility for the accuracy, completeness, or usefulness of any information, apparatus, product, or process disclosed, or represents that its use would not infringe privately owned rights. Reference herein to any specific commercial product, process, or service by trade name, trademark, manufacturer, or otherwise, does not necessarily constitute or imply its endorsement, recommendation, or favoring by the United States Government or the University of California. The views and opinions of authors expressed herein do not necessarily state or reflect those of the United States Government or the University of California, and shall not be used for advertising or product endorsement purposes.

This work was performed under the auspices of the U.S. Department of Energy by the University of California, Lawrence Livermore National Laboratory under Contract No. W-7405-Eng-48.

This report has been reproduced directly from the best available copy.

Available electronically at http://www.doe.gov/bridge

Available for a processing fee to U.S. Department of Energy and its contractors in paper from

U.S. Department of Energy

Office of Scientific and Technical Information

P.O. Box 62

Oak Ridge, TN 37831-0062

Telephone: (865) 576-8401

Facsimile: (865) 576-5728

E-mail: reports@adonis.osti.gov

Available for the sale to the public from

U.S. Department of Commerce

National Technical Information Service

5285 Port Royal Road

Springfield, VA 22161

Telephone: (800) 553-6847

Facsimile: (703) 605-6900

E-mail: orders@ntis.fedworld.gov

Online ordering: http://www.ntis.gov/ordering.htm

OR

Lawrence Livermore National Laboratory

Technical Information Department's Digital Library

http://www.llnl.gov/tid/Library.html 


\section{Introduction}

Building 251 is the Lawrence Livermore National Laboratory Heavy Elements Facility. Operations that involved heavy elements with uncontained radioisotopes including transuranic elements took place inside of glove boxes and fume hoods. These operations included process and solution chemistry, dissolutions, titrations, centrifuging, etc., and isotope separation. Operations with radioactive material which presently take place outside of glove boxes include storage, assaying, packing and unpacking and inventory verification. Wastes generated inside glove boxes will generally be considered TRU or Greater Than Class C (GTCC). Wastes generated in the RMA, outside glove boxes, is presumed to be low level waste. This process knowledge quantification method may be applied to waste generated anywhere within or around B251. The method is suitable only for quantification of waste which measures below the MDA of the Blue Alpha meter (I.e. only material which measures as Non-Detect with the blue alpha is to be characterized by this method).

\section{Waste Characterization}

Radiological Characterization for transuranic nuclide contaminated waste coming from the Heavy Elements Facility requires both an isotopic breakdown and a quantification of the radionuclides in the waste. A general isotopic breakdown was developed based upon inventory records and other process knowledge. Information specific to distribution development can be found in Reference 1. Additional project specific isotopic distributions may be developed using inventory controls, process knowledge, and historical analytical data. As additional distributions are developed they will be documented on a case-by-case basis in later revisions of this document or project specific documentation such as PKEs. Isotopic quantification will be done using information from the radiological control program in the facility, direct survey, gamma spectroscopy, laboratory analytical, or other documented methods. Specific approaches to characterization other than this MDA method will be documented as they are developed and put into use.

Table 1

B251 MDA General Radionuclide Distribution

\begin{tabular}{|c|c|c|}
\hline Isotope & Activity Fraction & Activity \% \\
\hline Am-241 & 0.22 & 22 \\
\hline Cm-244 & 0.41 & 41 \\
\hline Pu-238 & 0.32 & 32 \\
\hline U-232 & 0.05 & 5 \\
\hline
\end{tabular}


The portion of the facility where the radioactive material is handled in glove boxes is maintained as a clean work environment, i.e. no loose contamination in the occupied areas. Several routine procedures are performed to ensure that the facility is maintained as a clean work area. Routine swipes are presently taken both monthly and quarterly throughout the RMA. Hands and shoes are monitored for contamination each time a person exits the RMA. When contamination is found by any of these methods the source of the contamination is located and decontaminated or encapsulated. Hallways within the RMA are maintained as swipe free. Likely sources for contamination in the RMA include breaches in glove boxes and other containers, fume hoods, and from materials currently encapsulated under floor tiles, paint, etc., from past spills.

The alpha survey instrument used in B251 is a LLNL designed and manufactured instrument with an air proportional probe (Blue Alpha: LE751854). The minimum detectable activity (MDA) for this instrument under ideal conditions is approximately $50 \mathrm{cpm}$ with $50 \%$ efficiency $=\sim 100 \mathrm{dpm}$. This portable instrument has a $100 \mathrm{~cm}^{2}$ probe. The hand and shoe instruments also use an air proportional probe that is approximately $500 \mathrm{~cm}^{2}$ with approximately the same MDA.

\section{Assumptions:}

1. Waste material is contaminated on one side and the contamination is equally distributed.

2. The waste has the same surface area per weight as 6 mil plastic. $6 \mathrm{mil}$ plastic sheet has a surface density of $12 \mathrm{mg} / \mathrm{cm}^{2}$.

3. The alpha meter used to measure the area is $50 \%$ efficient and the minimum detectable activity is $2.5 \mathrm{cpm} / \mathrm{cm}^{2}=\sim 5 \mathrm{dpm} / \mathrm{cm}^{2}$

4. All waste is contaminated at the MDA.

5. Meter background does not exceed $20 \mathrm{cpm}$.

Assumption 1 is generally true in that only one side of most items will come in contact with the radioactive material.

Assumption 2 provides a method to convert surface area to weight. Six-mil plastic was chosen because it is one of the lighter items disposed of as low level waste and therefore provides a conservative estimate of the activity in the waste. Low surface density values are conservative because they equate to higher activity per a given weight. The table below provides some of the surface density of items that may be found in the low level waste. 


\begin{tabular}{|c|c|}
\hline Item & Surface Density $\left(\mathrm{mg} / \mathrm{cm}^{2}\right)$ \\
\hline Six-mil Plastic Sheet & 12 \\
\hline 20\# Copier Paper & 10 \\
\hline Powderless Gloves & 20 \\
\hline Heavy Rubber Gloves & 48 \\
\hline Plastic and Launderable Shoe Covers & 120 \\
\hline Coverall Material & $19-28$ \\
\hline Twelve-mil Plastic & 24 \\
\hline
\end{tabular}

Assumption 3 uses a MDA of $2.5 \mathrm{cpm} / \mathrm{cm}^{2}=\sim 5 \mathrm{dpm} / \mathrm{cm}^{2}$ which is 5 times the actual MDA of $0.5 \mathrm{cpm} / \mathrm{cm}^{2}=\sim 1 \mathrm{dpm} / \mathrm{cm}^{2}$ for the LLNL Blue Alpha Meter. A MDA of $0.5 \mathrm{cpm} / \mathrm{cm}^{2}=\sim 1 \mathrm{dpm} / \mathrm{cm}^{2}$ is for the ideal flat and smooth surface and the MDA of $2.5 \mathrm{cpm} / \mathrm{cm}^{2}=\sim 5 \mathrm{dpm} / \mathrm{cm}^{2}$ is to provide for surfaces that are not ideal.

Assumption 4 provides an estimate of the quantity of activity in the waste. By using the MDA for all material this will help ensure that the quantity of alpha emitters in the waste is not under estimated.

By converting surface area contaminated at MDA weight it is determined that the waste will contain approximately $0.20 \mathrm{nCi}$ per gram.

$$
\frac{\left(\frac{5 d p m}{\mathrm{~cm}^{2}}\right)\left(\frac{1 n C i}{2,220 \mathrm{dpm}}\right)}{\left(\frac{1 \mathrm{~g}}{1000 \mathrm{mg}}\right)\left(\frac{12 \mathrm{mg}}{\mathrm{cm}^{2}}\right)}=0.19 \frac{n C i}{\mathrm{~g}} \approx 0.20 \frac{\mathrm{nCi}}{\mathrm{g}}
$$

Efficiency of Detector $=50 \%$

Minimum Detectable Activity $=\left(2.5 \mathrm{cpm} / \mathrm{cm}^{2}\right) /(0.5)=5 \mathrm{dpm} / \mathrm{cm}^{2}$

Conversion from dpm to $\mathrm{nCi} ; 2.22 \times 10^{3} \mathrm{dpm}=1 \mathrm{nCi}$

Assumption 5 is an administrative control placed over the process to ensure the MDA is not unreasonably high. This is important to eliminate the potential for contamination being missed due to surveys being conducted in high background areas. The $20 \mathrm{cpm}$ limit on background coincides with the current instrument shop guideline on calibration of the blue alpha meter. 
Justification for using MDA for activity calculations;

Waste will undergo direct survey with the blue alpha meter. Waste with measurable contamination will be segregated from waste that is at or below the MDA of the blue alpha meter. Blue alpha meter background count rate cannot exceed $20 \mathrm{cpm}$ when items are surveyed. Segregation of contaminated waste from $<$ MDA waste will be conducted when waste is being packaged. Waste with measurable contamination will be quantified based upon actual instrument readings, or gamma spectroscopy, or other documented methods as appropriate. The MDA characterization method is only for material with no measurable contamination.

\section{Conclusions:}

By using the MDA level to determine the quantity of alpha emitters in a waste container it can be ensured that containers containing TRU or GTCC levels of alpha emitters will not end up in the low level waste stream.

\section{References:}

1. Jared Dominick to WCP Critical Memo File, HWM/WGS Memo, WCP00143, "Development of B251 MDA Radionuclide Distribution". 12 October 2000. 